\title{
Online komunity v České republice: Analýza členů a jejich sociálního kontextu
}

\section{Online Communities in the Czech Republic: Analysis of Members and their Social Context}

\author{
Martina Veselá, David Šmahel
}

\begin{abstract}
The article deals with the subject of members of various online communities in the Czech Republic. The aim of this study was to discover differences between community participants and non-participants in various characteristics. We analyzed a representative sample of the Czech population. The data for the analysis were collected during face-to-face interviews conducted under the auspices of the World Internet Project: Czech Republic 2007. The whole sample consisted of 1586 respondents aged 12 and up, out of which 256 respondents stated that they were or had been regular members of an online community. First, the demographic profile of the sample of online community members was examined, with particular focus on age, marital status and social status. We then looked at whether there are differences between those who participate in online communities and those who do not regarding the amount of interpersonal contact with family members and friends. Another aspect we focused on was whether online community members have a closer relationship with their online friends.
\end{abstract}

KEYWORDS Internet, online communication, online community, social network, virtual community

\section{Úvod}

Spolu s tím, jak se internet stává pro mnoho lidí běžnou součástí jejich každodenního života, existují mnohé sociální aktivity paralelně v běžném životě a ve své virtuální podobě. Př́ikladem může být online seznamování (Vaculík a Hudeček 2005), diskusní a zájmové servery, kde se setkávají a předávají si zkušenosti lidé, které spojuje společné téma (McKenna a kol. 2002), vznikají svépomocné online spolky na podporu lidí s určitým problémem či nemocí atd. (Bargh a McKenna 2004, Nip 2004).

Vyvstává otázka, jakým způsobem a do jaké míry internet zasahuje do společenského života svých uživatelů. Ukazuje se, že vliv internetu není možné označit za jednoznačně pozitivní či negativní. Internet může přispívat k rozvíjení mezilidských vztahů tím, že rozšiřuje možnosti komunikace a vzájemnou podporu tak činí dostupnější. Na druhou stranu možnosti,

Sociální studia. Fakulta sociálních studií Masarykovy univerzity, 2/2009. S. 55-72. ISSN 1214-813X.

Studie vznikla s podporou výzkumného záměru „Psychologické a sociální charakteristiky dětí, mládeže a rodiny, vývoj osobnosti v době proměn moderní společnosti““ (MSM0021622406), který probíhá na Fakultě sociálních studií Masarykovy univerzity. 
jako je online nakupování či vyřízení úředních záležitostí přes internet, způsobují, že lidé mají méně důvodů opustit domov a setkávat se s lidmi osobně (Tyler 2002, Franzen 2000).

Jednou z uváděných hypotéz ohledně vlivu používání internetu na člověka, je tzv. timedisplacement hypothesis (předpoklad přesunutí času) (Nie 2001; Nie, Hillygus 2002a,b). Tato hypotéza vychází z premisy, že čas je omezená veličina, a tedy že čas strávený online je nutně na úkor jiných aktivit, včetně času stráveného s lidmi. Tento názor podporují výsledky výzkumu Niea a Erbringa (2002), které odhalily, že 15 \% uživatelů trávících na internetu více než 10 hodin týdně uvádí, že internet způsobil pokles množství času stráveného s práteli a s rodinou. Způsob interpretace těchto dat ale kritizují např. Bargh a McKenna (2004), kteří upozorňují, že výsledky spíše ukazují na to, že 95 \% respondentů neudává žádné změny v čase stráveném s blízkými lidmi a zároveň, že skutečný přesun času nastal na úkor sledování televize a čtení novin, nikoli sociálních aktivit. Podobně Galácz a Šmahel (2007), kteří srovnávali výsledky reprezentativních výzkumů ve čtyřech státech (USA, Mad’arsko, Česká republika a Singapur), zjistili, že většina respondentů ve všech zemích (73-89 \%) uvádí, že čas, který tráví se svojí rodinou, se v souvislosti s používáním internetu nezměnil.

Výsledky výzkumů týmu Roberta Krauta ukázaly, že vliv používání internetu na mezilidské vztahy se může měnit v závislosti na délce používání internetu (Kraut a kol. 1998, 2002). První část výzkumu z roku 1998 nejprve naznačila, že ti, kteří používali internet hodně, se méně zapojovali do společenských aktivit. Komunikace $\mathrm{v}$ rodině se kvưli internetu omezila, snížil se počet lidí, se kterými byli respondenti aktivně v kontaktu. Tyto změny přitom nastaly i v př́ípadě, že dominantní činností na internetu byla komunikace. Pokračování studie (Kraut a kol. 2002) naopak ukázalo, že časté používání internetu bylo spojeno s větším zapojením uživatelů do dění rodiny, komunity a přátelských vztahů.

Některé výzkumy ukazují, že sociální vazby internetových uživatelů se stávají bohatší jednak ve smyslu získání širší sítě prátel (napřs. Hlebec a kol. 2006), a také s ohledem na frekvenci a množství času věnovaného interpersonálním kontaktům (např. Horrigan a Rainie 2002, Mandelli 2002). Dle Cogeta a kol. (2002) internet minimalizuje komunikační bariéry dané časem a místem, zvyšuje efektivitu a rychlost transakcí a šetří tím čas pro další aktivity, tedy také na osobní setkávání.

Virtuální prostor poskytuje možnost udržovat vztahy, které by kvůli vzdálenosti či jiným překážkám jen obtížně pokračovaly, stejně jako utvářet nové vazby a společenství, např. právě virtuální komunity, které jsou předmětem této studie.

\section{Virtuální komunity}

Komunitu lze definovat jako sít' mezilidských vztahů, která zúčastněným poskytuje určité zázemí, podporu, informace, skupinovou identitu a pocit, že někam patří (Wellman 2001). Komunita se obvykle formovala na základě fyzické blízkosti členů, roli hrály společné zájmy, setkávání se ve školním či pracovním kolektivu atd. (Gotved 2002).

Wellman a Gulia (1997) ovšem upozorňují, že povaha komunit se významně změnila již před rozšriřením internetu. Německý sociolog Ferdinand Tönnies už v roce 1887 rozlišil mezi tradiční komunitou, tzv. Gemeinschaft, a moderní společností, tzv. Gesellschaft (např. Memmi 2006). „Gemeinschaft“ je založena na silných osobních vztazích v malé skupině a na pocitu 
sounáležitosti; jejím př́kladem je rodina. Tato tradiční komunita je vázána na omezený prostor a je spíše uzavřená. Oproti tomu v „Gesellschaft“ jsou vztahy více neosobní, volnější, přechodné a funkční, skupinová identita je slabá; př́kladem mohou být kontakty navazované ve velkém městě či firmě (Memmi 2006).

Dnešní komunita už tedy není nutně chápána v pojmech fyzické blízkosti, ale spíše na základě existence sociálních sítí. Tuto změnu umožnily telefony, letadla či automobily, díky kterým není možnost udržování mezilidských vztahů tolik vázána na určité místo. Významnou charakteristikou současných komunitních sítí (včetně těch virtuálních) je podle Wellmana (2001) to, že sdružují osoby především na základě vzájemných sympatií a zájmů. Obdobně Rheingold (1992) virtuální komunity vnímá jako odraz potřeby lidí sdružovat se i v době, kdy tradiční komunity ztrácejí na významu a již neposkytují takové zázemí jako dříve. Svým způsobem jsou pro něj tedy náhradou či nástupcem tradičních vazeb. Oproti tomu Daniel Memmi (2006) považuje oblíbenost online komunikace a virtuálních skupin spíše za projev pokračujícího narůstání neosobnosti a instrumentálnosti sociálních vztahů. Říká, že většina virtuálních komunit je založena spíše na poutech, která jsou povrchní a nestálá.

Virtuální komunity však mají mnoho podob a povaha vazeb v nich může být značně rozdílná. Část virtuálních komunit je pokračováním reálných skupin a online komunikace zde pomáhá překlenout prostor a čas mezi osobními setkáními lidí (např. Howard 2001; Kollock, Smith 1999; Wellman a kol. 1996). Jiné komunity mohly vzniknout jako setkání cizinců se společným zájmem, přičemž část vztahů se mohla přenést i do reality. Uvažujeme-li tedy o virtuální komunitě, je třeba mít na paměti, že dichotomie online versus offline komunita není zcela na místě. Obě podoby komunit se navzájem prolínají a doplňují (Nip 2004).

Dělení virtuálních komunit na dva typy navrhují autorky Boyd a Ellison (2007). Prvním typem jsou komunity organizované primárně kolem společného tématu, ke druhému typu patří ty, u kterých jsou jako pojící prvek podstatní lidé. První typ spíše umožňuje spojovat cizince, druhý podporuje pokračování stávajících vazeb (Boyd, Ellison 2007). Neznamená to ovšem, že by komunity seskupené kolem lidí nutně byly spojeny pevnějšími vazbami, jak ukazuje př́klad Facebooku.

Facebook patří ke společenským sítím (,social network sites“ - SNS), které se dnes stávají velmi populárními (Facebook udává více než 200 milionů aktivních uživatelů) ${ }^{1}$. Podle Boyd a Ellison (2007) se jedná o komunitu organizovanou primárně kolem lidí. Na Facebooku se obvykle nevytvárí nové vazby, ale skrze veřejný seznam „přátel“ se zviditelňují již existující sociální sítě převzaté z reálného života. Pojem „přítel“ je ale v tomto kontextu relativní, uživatelé Facebooku mají nezř́ídka 200 a více přátel. Aktualizují se zde rovněž latentní a vzdálené vazby a na seznamu prátel se pak ocitají lidé, kteří se ve skutečnosti znají jen málo. Uživatelův profil, veřejný seznam prátel a možnost sdílení informací považují Boyd a Ellison (2007) za určující části sociálních sítí. Tyto prvky ale nejsou nové, u sociálních sítí došlo $\mathrm{k}$ jejich spojení a především $\mathrm{k}$ jejich využití $\mathrm{k}$ propojování a rozšiřování sociálních sítí a ke vzájemnému sdílení osobních informací. V současnosti pak adoptují tyto prvky a získávají povahu sociálních sítí i portály určené původně ke sdílení mediálního obsahu (např YouTube, MySpace) či k blogování (Twitter). 


\section{Metoda}

V tomto článku se zabýváme tématem virtuálních komunit, přičemž analyzujeme data ze „Světového projektu o internetu: Česká republika 2007“ (World Internet Project: Czech Republic 2007). Dílčí výsledky srovnáme s daty z výzkumu „World Internet Project“ z roku 2006, které popisovaly stejnou problematiku (Štětka a Šmahel 2008). Sběr dat výzkumu proběhl v záŕí 2007, data sbírala agentura STEM prostřednictvím osobních rozhovorů tazatelů s respondenty. Vzorek byl vybrán pomocí kvótního výběru, prričemž byl reprezentativní vzhledem k věku, pohlaví, vzdělání a bydlišti respondenta. Celý vzorek čítal 1586 respondentů ve věku 12 až 88 let, z toho 869 osob se označilo za uživatele internetu. Výzkum byl součástí širšího projektu „World Internet Project“, v rámci kterého jsou sbírána a srovnávána data o uživatelích internetu z celého světa (viz www.worldinternetproject.net). V tomto článku analyzujeme údaje pouze o českých účastnících online komunit, přičemž otázky týkající se komunit nebyly kladeny v jiných zemích, byly součástí výhradně českého projektu.

$\mathrm{V}$ rámci „Světového projektu o internetu“ $\mathrm{v}$ ČR byly respondentům položeny následující otázky: „Chodíte v současnosti na internetu pravidelně někam, např́klad na nějaký server, kde potkáváte stejné lidi či skupiny lidí, např́ílad na chaty, diskusní fóra, hry a jiné komunitní portály, např. lidé.cz?“ a „Chodil(a) jste pravidelně do takové skupiny někdy v posledních čtyřech letech?“. S ohledem na odlišnou konotaci slova „komunita“v českém jazyce jsme zvolili otázku, která se na účast ve virtuální komunitě ptá opisem významu tohoto slova - jakkoliv si uvědomujeme, že tento opis není zcela přesný. Tyto otázky nám umožnily vybrat populaci členů online skupin, respektive komunit $\mathrm{v} \breve{C}$, a tato data jsme následně analyzovali ve vztahu k vybraným nezávislým proměnným.

\section{Výzkumné otázky a hypotézy}

První část výzkumu sleduje socio-demografické charakteristiky účastníků komunit. Zjišt'ujeme v ní, jak se účastníci online skupin liší ve vybraných socio-demografických ukazatelích od ostatních uživatelů internetu.

Předchozí výzkumy z prostředí českého internetu (např. Štětka, Šmahel 2008; Šmahel 2008) ukazují, že věk je významným rozlišujícím faktorem v přístupu k internetu i virtuálním komunitám. Podle výsledkủ Štětky a Šmahela (2008) spadá největší podíl uživatelů komunit do věkové skupiny 12 až 15 let, v níž virtuální komunity pravidelně navštěvuje $40 \%$ uživatelů internetu. Na výsledky výzkumu Štětky a Šmahela analyzujícího data z roku 2006 navážeme a ukážeme vývoj v miře využití online komunit dle věkových skupin mezi lety 2006 a 2007. Jelikož od roku 2007 se začaly sociální sítě poměrně rychlým tempem rozvíjet (v zahraničí především Facebook a MySpace, u nás v té době především Lide.cz), předpokládáme, že dojde k nárůstu používání online komunit:

H1: Od roku 2006 do roku 2007 došlo k náriostu míry participace v online komunitách ve všech věkových skupinách.

Vedle věku budeme navíc zkoumat rodinný stav a sociální status účastníků komunit, přičemž předpokládáme, že obě charakteristiky jsou ve vztahu k míře využití online komunit:

H2: Účast ve virtuálních komunitách souvisí s rodinným stavem.

H3: Účast ve virtuálnich komunitách souvisí se sociálním statusem. 
Tyto souvislosti budeme zkoumat na rozdílech mezi uživateli internetu, kteří se online komunit účastní, a uživateli internetu, kteří online komunity nenavštěvují.

Druhá část výzkumu se věnuje interpersonálním kontaktům účastníků virtuálních komunit. Dosavadní výzkumy opakovaně ukazují, že internet slouží především ke komunikaci a pomáhá při udržování již stávajících vztahů (Bargh, McKenna 2000; Hlebec 2006; Rheingold 1993). Zajímá nás, zda účast ve virtuální komunitě může mít vliv na množství kontaktů a míru setkávání se s druhými lidmi.

Štětka a Šmahel (2008) v rámci výzkumu „Světový projekt o internetu: Česká republika 2006“ zjistili, že členové virtuální komunity trávili v průměru téměř o tř̀ hodiny týdně více se svými reálnými přáteli než ostatní uživatelé internetu. Mezi účastníky komunit a ostatními uživateli nebyly zaznamenány významné rozdíly v čase stráveném s rodinnými příslušníky. Tyto výsledky ověŕme a rozšíríme o analýzu, zda má účast v online komunitě vliv na intenzitu kontaktu s rodinou a s přáteli, která nebyla součástí výzkumu z roku 2006. Vzhledem k tomu, že v online skupinách se mnohdy scházejí již etablovaní přátelé (Kollock, Smith 1999; Wellman a kol. 1996), přepokládáme, že členové těchto skupin budou udávat častější kontakt s přáteli (objem vzájemného kontaktu bude vyšší právě o čas strávený společně online). Naopak kontakt s rodinou může být nižší, protože virtuální komunita nebude sloužit jako společný komunikační prostor rodičů a dospívajících:

H4: Účast ve virtuální komunitě ovlivňuje kontakt s rodinou.

H5: Účast ve virtuálni komunitě ovlivňuje kontakt s přáteli.

Další sledovanou oblastí jsou vztahy s online prráteli. Fungování mnohých online skupin je založeno na společně sdílených zájmech (Wellman 2001), členové se opakovaně setkávají a tráví spolu určité množství času. Jsou tak dány jisté podmínky pro vznik bližších vztahů mezi členy skupiny. Zde si proto klademe za cíl zjistit, zda účastníci virtuálních komunit přistupují k online prátelstvím stejně či naopak jinak než ostatní uživatelé internetu:

H6: Účast ve virtuální komunitě souvisí s podobou online prátelských vztahů.

\section{Popis vzorku}

Asi polovina účastníků výzkumu (55\%, N = 869) odpověděla, že pravidelně používá internet, přičemž průměrný věk v této skupině je 33 let. Tento údaj vyjadřuje vzhledem k reprezentativnímu charakteru výzkumu podíl uživatelů internetu na populaci České republiky. Na výše uvedenou otázku ohledně účasti v online komunitě odpovědělo pozitivně 30,8 \% uživatelů internetu $(\mathrm{N}=267)$, což představuje $16,9 \%$ celé populace. Se skupinou uživatelů online komunit pracujeme v dalších analýzách, a proto nyní popíšeme její demografické charakteristiky.

Mezi členy online komunit mírně převažují muži - jejich podíl činí 53,2 \%, zatímco v rámci celé zkoumané populace to je 48,6 \%. Průměrný věk uživatele, který má zkušenost s online skupinou, je 27 let. Největší podíl uživatelů komunit pak tvoří adolescenti ve věku 12 až 19 let, kteří představují 41,9 \% členů online skupin. Věková skupina mladých dospělých (20-26 let) tvoří 16,1 \%, dospělí ve věku 27 až 49 let 35,2 \% a uživatelé online skupin nad 50 let pouze $6,7 \%$. 
Z hlediska sociálního statusu představují 34,6 \% uživatelů online komunit studenti, 38,7 \% zaměstnanci, 9,4 \% žáci základních škol, 4,9 \% ženy v domácnosti, 7,2 \% podnikatelé a živnostníci, $3 \%$ nezaměstnaní a zbylých $2,3 \%$ důchodci. Dále dle rodinného stavu účastníka online komunity tvoří 38,7 \% svobodní s partnerem, 28,7 \% svobodní bez partnera, $26 \%$ vdané/ženatí a $6,6 \%$ rozvedení.

Nejčastější navštěvovanou online skupinou byl server www.lide.cz, který spolu s dalšími komunitními portály uvedlo 105 respondentů a respondentek. Následují chaty (43 respondentů), zájmové skupiny (např. www.csfd.cz ${ }^{2}$ uvedlo 29 respondentů), seznamky (13), ICQ (11) a herní servery (10) - viz procentuální podíly typů komunit v Grafu 1. Nikdo z respondentů neuvedl Facebook, MySpace, Twitter nebo LinkedIn, což je pochopitelné vzhledem k tomu, že v době sběru dat (zář́ 2007) nebyl tento typ sociálních sítí v ČR mezi uživateli internetu př́liš rozšiřren. Podle orientačních statistik ${ }^{3}$ sledujících denní návštěvnost (daily unique visitors) získával Facebook v ČR první uživatele teprve na konci roku 2007. V tomto výzkumu tak sledujeme především účast $\mathrm{v}$ českých online komunitách, které předcházely rozšíření sítí Facebook, MySpace atd.

Graf 1: Nejčastěji navštěvované online skupiny v ČR - září 2007

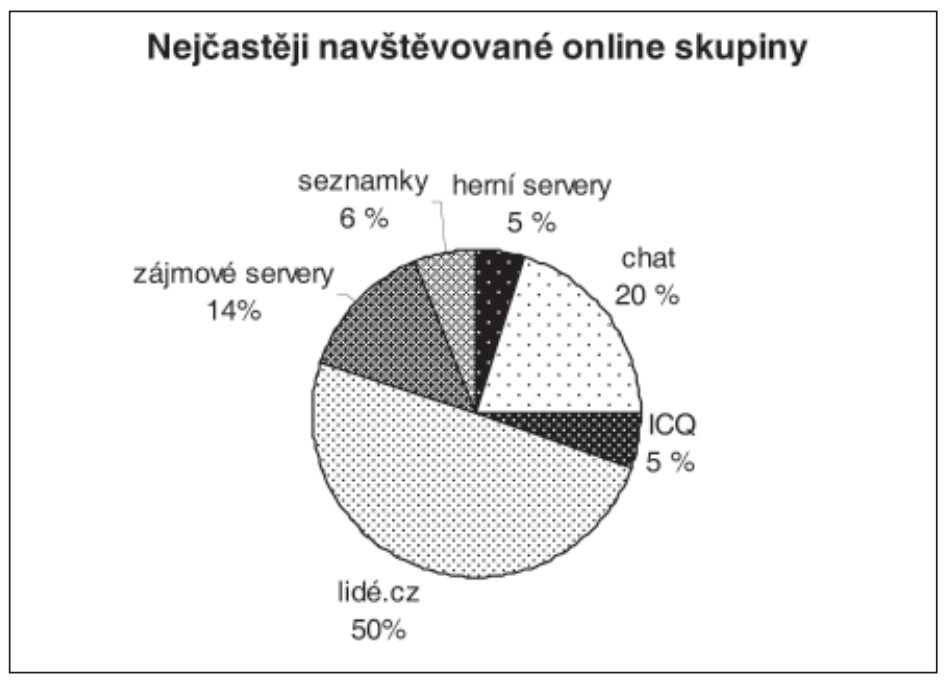

\section{Podíly uživatelů online komunit dle věku: jsou komunity jen pro mladé?}

Online komunity navštěvovalo v roce 2007 celkem 30,8 \% českých uživatelů internetu, v roce 2006 to bylo $22 \%$ uživatelů (Štětka, Šmahel 2008). Zajímalo nás dále, jaké jsou podíly

\footnotetext{
2 Československá filmová databáze.

3 GoogleTrends: http://trends.google.com/
} 
uživatelů internetu navštěvujících online komunity v různých věkových skupinách a jak se situace změnila od roku 2006. Jelikož nepoužíváme longitudinální data, ale dva reprezentativní soubory dat získané v intervalu jednoho roku, uvádíme srovnání v Grafu 2, který přehlednou formou zobrazuje př́slušné podíly ve věkových skupinách. Pro doplnění obrazu používání internetu v ČR jsme do grafu přidali také podíly uživatelů internetu pro jednotlivé skupiny za oba roky.

Graf 2: Podíl uživatelů internetu respektive účastníků komunit v rámci věkových kategorií

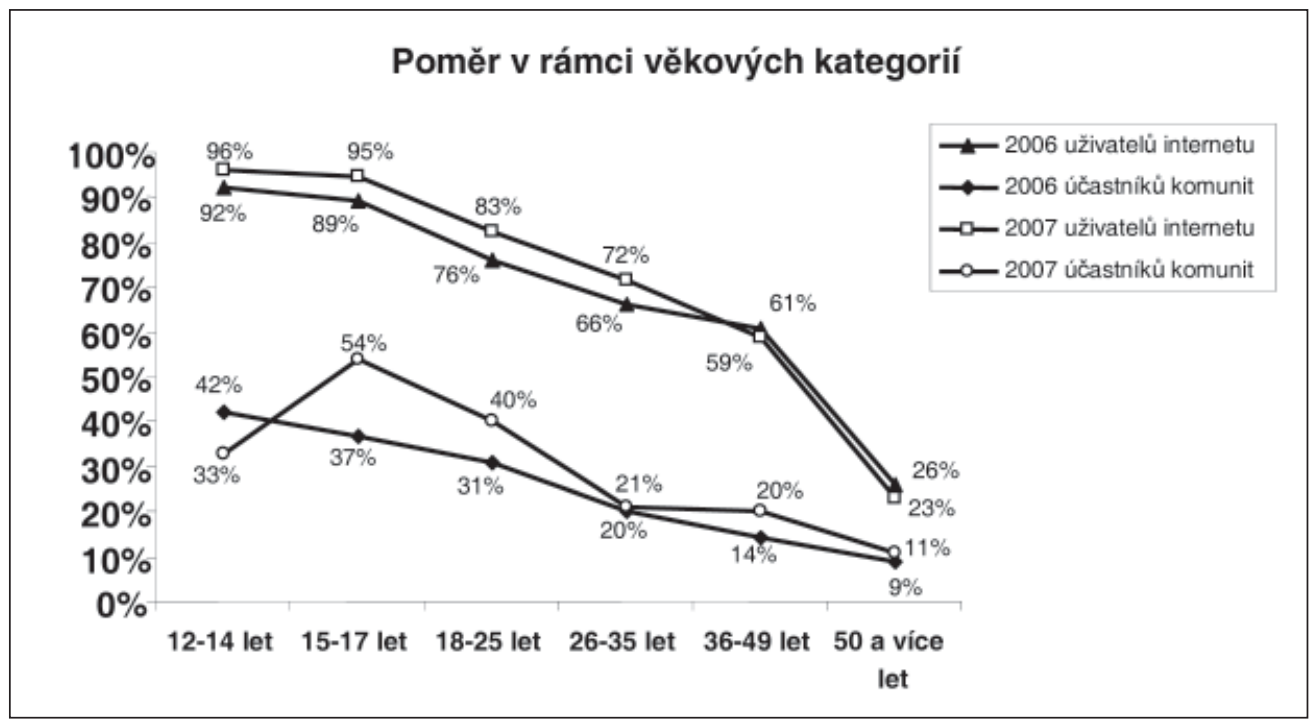

Vidíme, že největší nárůst (17 \%) v zapojování se do online komunit nastal u skupiny 15 až 17letých, naopak k největšímu poklesu ( $9 \%$ ) došlo u nejmladší skupiny 12 až 14 let. Je otázkou, jaké jsou důvody poklesu používání online komunit u nejmladších respondentů, jelikož se však jedná o poměrně malou skupinu v rámci celého vzorku ( 77 uživatelů internetu ve věku 12 až 14 let v roce 2007), je rozdíl v rámci statistické chyby. Hypotézu 1, která předpokládala nárůst počtu účastníků online komunit, tak můžeme přijmout jen zčásti, pro její úplné přijetí nemáme dostatečná data. Celkový nárůst o téměř $9 \%$ za rok však můžeme označit za signifikantní. Zajímavé je, že nárůst používání českých online komunitních serverů do určité míry kopíroval trendy v zahraničí, kde docházelo v té době k boomu Facebooku, MySpace atp.; tyto zahraniční servery neměly současně prozatím své české verze, a nebyly tak u nás rozšiřreny. Domácím poskytovatelům se tak podařilo na omezenou dobu zajistit náhradu těchto zahraničních serverů, avšak ty své české protějšky v budoucnu stejně „převálcovaly“ mnohem masivnější kampaní a zajistily si rozšíření mezi české uživatele internetu. 


\section{Srovnání podle rodinného stavu: chodí do komunit jen svobodní?}

Naší další otázkou je, zda se účastníci a neúčastníci online komunit liší podle př́slušnosti $\mathrm{k}$ rodinnému stavu. Výsledky kontingenční tabulky naznačují, že rozdíly mezi oběma skupinami z hlediska rodinného stavu existují. ${ }^{4}$ Ve skupině účastníků online komunit je $28,5 \%$ svobodných bez partnera proti $20,6 \%$ uživatelů se stejným statusem, kteří se komunit neúčastní; v př́ípadě svobodných osob s partnerem je poměr 38,5\% účastníků proti $20,4 \%$ neúčastníkům a v př́ípadě vdaných/ženatých je jen 25,8 \% účastníků proti $46,2 \%$ neúčastníkủm online komunit. Jelikož rodinný stav je, jak známo, výrazně ovlivněn věkem a jelikož jsou mladí lidé současně častěji uživateli online komunit, bylo třeba testovat uvedené rozdíly ještě jiným způsobem. Průměrný věk sňatku byl v ČR dle ČSÚ v roce 2007 okolo 30 let, a proto jsme dále sledovali rodinný stav účastníků a neúčastníků komunit od této věkové hranice. Zde se ukázalo, že rozdíly mezi účastníky a neúčastníky online komunit nejsou signifikantní. Jinými slovy, mezi členy obou skupin ve věku nad 30 let byly velmi podobné podíly svobodných, vdaných/ženatých i rozvedených.

Následně jsme testovali odlišnosti z hlediska rodinného stavu u adolescentů ve věku 12 až 19 let. Rozdíly u adolescentů jsou pouze na úrovni kategorií „,s partnerem“ versus „,bez partnera“, v našem vzorku byla pouze jedna vdaná dívka do 19 let (a žádný/á rozvedený/rozvedená). Ukázalo se, že rozdíly mezi mladými uživateli a neuživateli komunit jsou signifikantní: mezi uživateli online komunit je 55,2 \% svobodných bez partnera, zatímco mezi uživateli, kteří online komunity nenavštěvují, je tzv. singles dokonce 82,2 \%. Zajímavé je také zjišsění, že online komunit se výrazně častěji účastní dospívající, kteří mají partnera: mladých lidí s partnerem je mezi účastníky komunit $44,8 \%$ oproti $16,8 \%$ u neuživatelů online komunit. Ukazuje se tedy, že neplatí často rozšiřrený názor, že do online komunit chodí jen svobodní, kteří si tam hledají partnery. Naopak můžeme uvažovat o tom, že adolescenti s partnery a také více přáteli (jak ukazujeme dále) jsou častěji schopni rozvíjet své vztahy i na internetu, případně právě díky němu.

Hypotézu H2 předpokládající souvislosti účasti v online komunitách a rodinného stavu tak odmítáme pro dospělou populaci (zde nad 30 let), můžeme ji však přijmout po populaci adolescentů ve věku 12 až 19 let.

\section{Srovnání podle sociálního statusu: dominují studenti online komunitám?}

Zajímalo nás také, zda se účastníci online komunit liší od uživatelů internetu, kteří se komunit neúčastní, podle sociálního statusu. $Z$ hlediska celkových podílů různých sociálních skupin jsou podíly signifikantní, např. žáci a studenti tvoří $44 \%$ podílu účastníků online komunit, zatímco mezi ostatními uživateli internetu (tj. těmi, kteří se komunit neúčastní) je pouze $22,1 \%$ studujících. Skutečnost, že velkou část účastníků komunit tvoří žáci a studenti, není př̌kvapující. Roli zde hraje věk i dostatek času. Mezi účastníky komunit je pak 38,7 \% zaměstnanců, z uživatelů, kteří komunity nenavštěvují, je zaměstnáno 52,7 \% respondentů. Přesto, že zaměstnanec se podle těchto údajů spíše nestane členem virtuální skupiny, je podíl zaměstnanců mezi účastníky komunit poměrně významný. To může být dáno tím,

Test $\chi 2$ signifikantní na hladině min. 0,05 . 
že - podobně jako u studentů - je pro ně počítač s přístupem na internet běžným pracovním nástrojem.

Pokud však opět omezíme vliv věku a analyzujeme pouze skupinu 27 let a starší (předpokládáme pravděpodobné ukončení studia do 26 let věku), rozdíly nejsou signifikantní. V rozdělení na věkové skupiny nejsou rozdíly z hlediska statusu signifikantní dokonce pro žádnou věkovou skupinu. Věk je tedy rrídící proměnnou pro míru účasti v online komunitě. Hypotézu H3 tak můžeme zamítnout - účast v online virtuálních skupinách nesouvisí se sociálním statusem uživatele internetu.

\section{Srovnání podle sociálních kontaktů}

Údaje ze „Světového projektu o internetu“ z České republiky ve shodě s výzkumem Hlebce a kol. (2006) potvrzují, že lidé zúčastňující se života virtuální skupiny udávají vyšší průměrné počty reálných přátel. Štětka a Šmahel (2008) zjistili, že účastníci komunit mají v realitě v průměru 26 prátel, zatímco ostatní uživatelé internetu jen 20 přátel. Rovněž počet online přátel udávají členové virtuálních skupin vyšší, a to o deset. Data „Světového projektu o internetu“ z České republiky z roku 2007 se s těmito výsledky shodují, viz Tabulka 1. Zde vidíme navíc i průměrné počty blízkých přátel, ze kterých vyplývá, že podíl blízkých přátel v realitě je u obou srovnávaných skupin shodný a odpovídá zhruba třetině.

Tabulka 1: Počet přátel u členů a nečlenů online komunit ${ }^{5}$

\begin{tabular}{|l|l|l|l|l|l|}
\hline \multicolumn{2}{|c|}{} & $\begin{array}{l}\text { Přátel } \\
\text { online }\end{array}$ & $\begin{array}{l}\text { Z nich blízcí } \\
\text { přátelé }\end{array}$ & $\begin{array}{l}\text { Přátel } \\
\text { v realitě }\end{array}$ & $\begin{array}{l}\text { Z nich blízcí } \\
\text { přátelé }\end{array}$ \\
\hline \multirow{2}{*}{$\begin{array}{l}\text { Nikdy nebyl } \\
\text { v komunitě } \\
(\mathrm{N}=587)\end{array}$} & Průměr & $\mathbf{1 , 8}$ & $\mathbf{0 , 8}$ & $\mathbf{1 5 , 2}$ & $\mathbf{5 , 6}$ \\
\cline { 2 - 6 } & St. odch. & 5,367 & 2,678 & 15,618 & 6,135 \\
\hline $\begin{array}{l}\text { Byl nebo je } \\
\text { v komunitě } \\
(\mathrm{N}=267)\end{array}$ & Průměr & $\mathbf{1 0 , 0}$ & $\mathbf{3 , 5}$ & $\mathbf{2 0 , 9}$ & $\mathbf{7 , 3}$ \\
\cline { 2 - 6 } & St. odch. & 14,279 & 8,441 & 21,431 & 9,174 \\
\hline
\end{tabular}

Vliv internetu na sociální kontakt byl v rámci výzkumu zjišt’ován prostřednictvím otázky, zda používání internetu dle názoru respondenta snížilo nebo naopak zvýšilo kontakt s vybranou skupinou. Respondenti vybírali odpovědi na pětibodové škále od „výrazně snížilo“ po „výrazně zvýšilo“.

Co se vnímaných změn v kontaktu s rodinou týče, u obou sledovaných skupin se shodně zhruba třetina uživatelů vyjádřila, že se jejich kontakt s rodinou díky použivání internetu

Rozdíly v průměrech počtů přátel byly testovány pomocí ANOVA, přičemž ve všech čtyřech př́ípadech byl rozdíl signifikantní $(\mathrm{p}<0,05)$. 
zvýšil; ale $13 \%$ členů komunit oproti $6 \%$ uživatelů internetu bez zkušenosti s online komunitou uvádí snížení kontaktu s rodinou; ${ }^{6}$ tyto výsledky přehledně ukazuje Graf 3.

Oproti výsledkům z předchozího roku nyní přibylo uživatelů, kteří udávají navýšení kontaktu s rodinou. V roce 2006 se 19 \% uživatelů komunit vyjádřilo, že díky internetu jsou více v kontaktu s rodinou, v roce 2007 to bylo už $33 \%$ členů komunit, resp. $30 \%$ ostatních uživatelů internetu. ${ }^{7}$ Zda se jedná o pokračující trend a lidé začínají internet více využívat také ke kontaktu s rodinnými př́slušníky, by bylo potřeba ověřit dalšími výzkumy, které by navíc byly zaměřené na online komunity ve větším detailu.

Graf 3: Pohled respondentů na změny v kontaktu s rodinnou v kontextu používání internetu

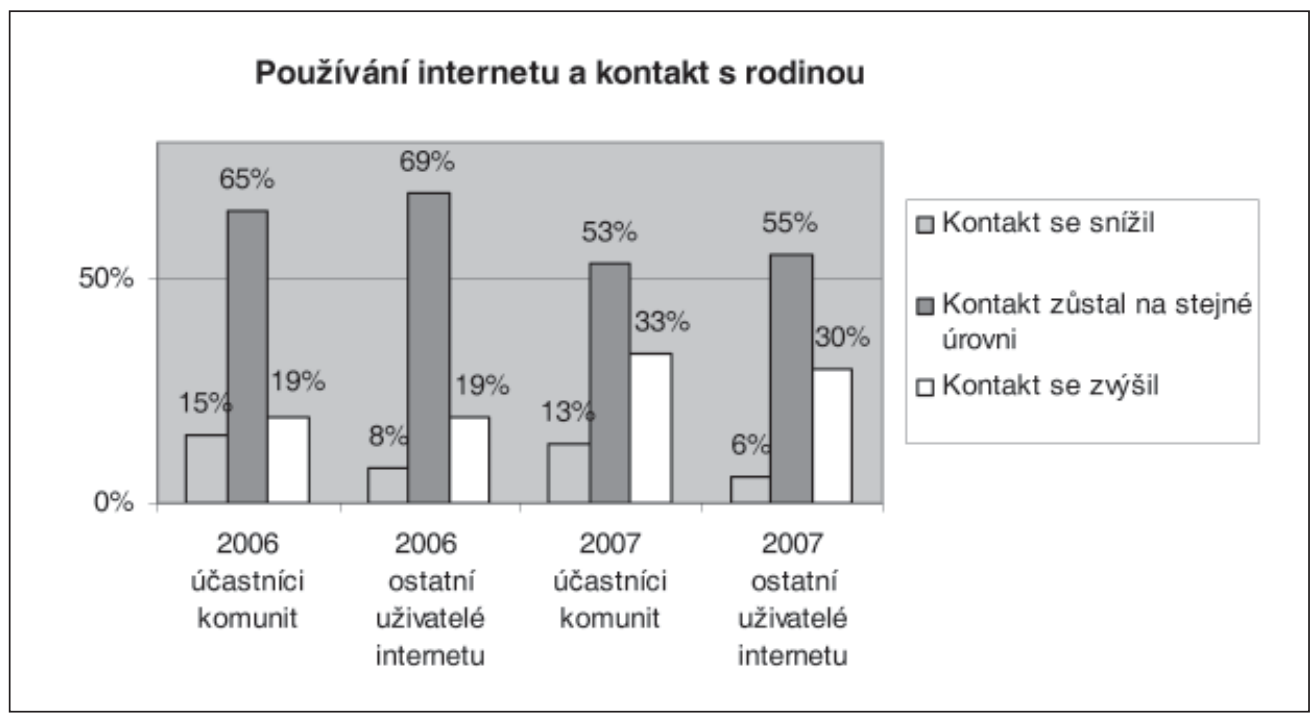

Test $\chi 2$ signifikantní na hladině min. 0,05 .

Vzhledem k tomu, že rozdíl mezi účastníky online komunit a ostatními uživateli ve vnímání vlivu internetu na jejich kontakt s rodinou je jen částečný, Hypotézu 4 týkající se vlivu internetu na kontakt s rodinou nepríímáme.

Hypotézu 5, která přepokládala vliv internetu na kontakt s přáteli, naopak přijmout lze. Sledované skupiny se v tomto př́padě neshodují při posuzování vlivu internetu. ${ }^{8}$ Celkem $65 \%$ uživatelů komunit vypovědělo, že díky internetu jsou více v kontaktu se svými práteli. Mezi ostatními uživateli internetu stejně odpovědělo jen $47 \%$ - tyto výsledky je možno vidět v přehledné podobě v Grafu 4.

\footnotetext{
$6 \quad$ Testováno $\chi 2$ sig. $<0,001$.

7 Testováno $\chi 2$ sig. $<0,05$.

8 Testováno $\chi 2$ sig. $<0,05$.
} 
Ukazuje se tedy, že díky internetu, potažmo účasti ve virtuálních komunitách, se kontakt s rodinou i s přáteli spíše zvýšil, přičemž internet podporuje častější kontakt s přáteli. To je dáno patrně také tím, že v komunitách participují častěji mladí lidé. Tyto výsledky by vyžadovaly další analýzu na specificky zaměřených vzorcích, např. pouze u skupiny mladých či dospělých.

Kromě výše uvedené otázky byli respondenti požádáni, aby se pokusili určit počet hodin, které týdně stráví s rodinou, př́teli, online činností či sledováním televize.

Graf 4: Pohled respondentů na změny v kontaktu s přáteli v kontextu používání internetu

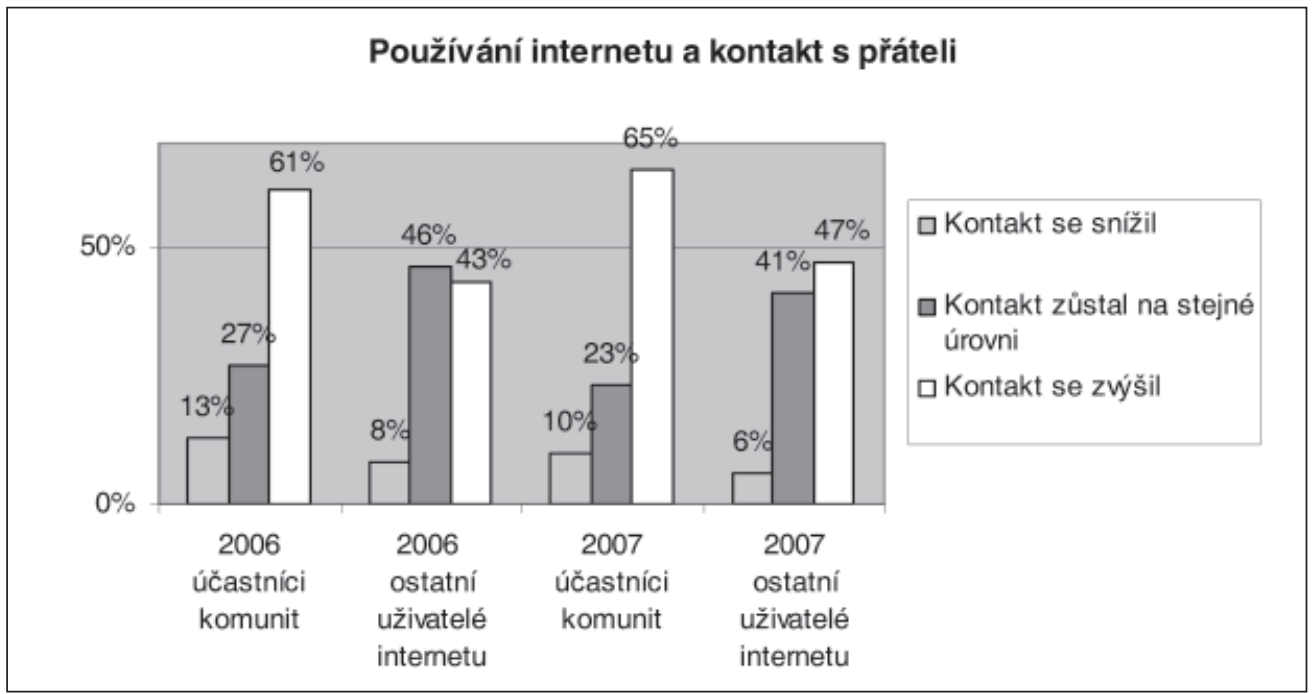

Výsledky „Světového projektu o internetu 2006“ ukázaly, že členové virtuálních skupin tráví se svými přáteli v průměru o tři hodiny více než ostatní uživatelé internetu (Štětka, Šmahel 2008). Stejný rozdíl se objevil i v našem výzkumu, viz Tabulka 2. Stejně jako v předchozím výzkumu se dále potvrzuje, že účast v komunitě nemá vliv na množství času, který respondent tráví s rodinou. ${ }^{9}$ Přitom ale na otázku , připojení k internetu, tráví členové Vaší domácnosti společně tváří v tvář méně času, více času nebo spolu tráví přibližně stejnou dobu jako předtím?" 38 \% členů virtuálních skupin odpovědělo, že má pocit, že díky internetu tráví s rodinou méně společného času, zatímco u ostatních uživatelů internetu má tento pocit jen $28 \%$. ${ }^{10}$ Účastníci komunit tedy mají oproti ostatním uživatelům spíše pocit, že vlivem internetu tráví s rodinou méně času, podle udávaného počtu hodin strávených s rodinou se ale tato hodnota neliší. Vidíme tedy kontradikci mezi tím, nakolik mají uživatelé online komunit pocit, že se kvưli používaní internetu změnil jejich kontakt s rodinou, a tím, jaký je odhadovaný počet hodin trávených s rodinou. Můžeme také

\footnotetext{
9 Testováno ANOVA sig. $<0,05$.

10 Testováno $\chi^{2}$ sig. $<0,05$.
} 
spekulovat o tom, že členové komunit trávili dříve s rodinou více času, tj. vlivem internetu se skutečně stýkají s rodinou méně než dřive. Roli ale také může hrát jejich špatný odhad, a to jak v počtu hodin, který respondenti udávají jako strávený s rodinou, tak v reflektování vlivu internetu na společně strávený čas.

Tabulka 2: Odhad respondentů o množství času stráveného vybranými činnostmi

\begin{tabular}{|l|l|l|l|l|l|}
\hline Hodin týdně: & $\begin{array}{l}\text { Celá populace } \\
(\mathbf{N}=\mathbf{1 5 8 2})\end{array}$ & $\begin{array}{l}\text { Uživatelé } \\
\text { internetu } \\
(\mathbf{N}=\mathbf{8 6 9})\end{array}$ & $\begin{array}{l}\text { Neuživatelé } \\
\text { internetu } \\
(\mathbf{N = 7 1 0 )}\end{array}$ & $\begin{array}{l}\text { Účastníci } \\
\text { komunit } \\
(\mathbf{N}=\mathbf{2 6 7})\end{array}$ & $\begin{array}{l}\text { Neúčastníci } \\
\text { komunit } \\
(\mathbf{N}=\mathbf{5 9 0})\end{array}$ \\
\hline $\begin{array}{l}\text { Sledování } \\
\text { televize }\end{array}$ & 17,2 & 14,5 & 20,6 & 14,4 & 14,6 \\
\hline Čtení novin & 4,3 & 3,6 & 5,2 & 3,3 & 3,7 \\
\hline S př́teli & 9,2 & 10,2 & 8,1 & 12,4 & 9,2 \\
\hline $\begin{array}{l}\text { Se členy } \\
\text { domácnosti }\end{array}$ & 26,1 & 25,8 & 26,4 & 25,4 & 26 \\
\hline
\end{tabular}

Sledované skupiny se také liší v počtu hodin strávených na internetu - uživatelé online komunit jsou na internetu v průměru 11,8 hodin týdně, zatímco ostatní uživatelé internetu jen 6,4 hodin týdně. Tabulka 2 ukazuje, že uživatelé internetu oproti respondentům, kteří internet nepoužívají, tráví významně méně času u televize a čtením novin. Tento rozdíl je signifikantní také pro mladé do 26 let: mladí uživatelé internetu se dívají na televizi průměrně 13,7 hodin týdně, zatímco neuživatelé internetu 19 hodin týdně. Televize a internet jsou tedy v konkurenčním vztahu, většina uživatelů používá internet částečně právě na úkor televize. Součet hodin trávených u internetu plus u televize je však u uživatelů internetu typicky vyšší (zde v součtu průměrně 24 hodin) než hodiny trávené u televize neuživateli internetu (průměrně 20,6 hodin). Můžeme tak říci, že v souvislosti s používáním internetu narostl čas, který tráví lidé s médii.

\section{Srovnání podle vztahu $\mathrm{k}$ online přátelům}

Další oblastí, kterou „Světový projekt o internetu“ zjišt'oval, je, jak uživatelé internetu přistupují k přátelstvím vzniklým online.

Rozdíl mezi účastníky online komunit a uživateli internetu, kteří komunity nenavštěvují, jsme nalezli u otázky, zda s online prráteli řeší svá intimní témata. Členové virtuálních komunit jsou takovému svěřování nakloněni více (30\% oproti $16 \%) .{ }^{11} \mathrm{Na}$ výrok „Neměl(a) bych problém se svých online přátelství vzdát“ odpovědělo kladně $45 \%$ těch, kteří jsou v nějaké online komunitě, oproti 58 \% těch, kteří v ní nejsou. Svých online přátel by se tedy vzdávali méně ochotně, než lidé, kteří nemají zkušenost s virtuální skupinou. ${ }^{12}$ Oproti tomu se statis-

11 Testováno $\chi 2$ sig. $<0,05$.

12 Testováno $\chi 2$ sig. $<0,05$. 
ticky významný rozdíl neprojevil u většiny dalších otázek. Nelišila se například vyjádření participantů a neúčastníků online komunit $\mathrm{k}$ tvrzení „Ke svým online přátelům necítím žádné závazky“, přičemž s tímto výrokem souhlasilo okolo 59 \% uživatelů internetu. Současně asi $68 \%$ u obou skupin kladně odpovídalo, že „mí online prátelé jsou jako osobnosti podobní mým přátelům z reálného života“. Můžeme se tedy ptát, co odlišuje přátele z reálného života od těch virtuálních, respektive na základě jakých skutečností uživatel někoho označí za svého online př́tele. Stejně tak lze uvažovat o tom, jak v tomto kontextu respondenti rozuměli pojmu „závazky vůči online prátelům“. Pokud se s některými svými přáteli stýkají pouze online, zřejmě ani nevznikají situace či př́ležitosti k závažným slibům a jejich plnění. Roli hraje i anonymita a možnost danému online př́teli již nenapsat či se pro něj učinit „,neviditelným“" ${ }^{13}$ což př́padné neplnění slibů usnadňuje. Toto se pak nevylučuje s tím, že se uživatelé internetu neradi svých online přátel vzdávají - dokud je vztah bezproblémový a nevyžaduje od uživatele žádné oběti, není důvod přátelství přerušovat.

Z výše uvedeného vyplývá, že Hypotézu 5, která říká, že účastníci komunit mají bližší vztahy se svými online práteli, nelze přijmout, členství ve virtuální skupině se neukázalo být rozlišujícím faktorem.

\section{Diskuze}

Zjištěné výsledky ukazují, že lze nalézt určitá specifika u uživatelů internetu, kteř́ se zapojují do života online komunit.

Online skupiny pravidelně navštěvuje velký podíl dospívajících ve věku 15-17 let (54\%). Toto zjištění podporuje předpoklad, že pro dospívající je důležité být součástí nějaké skupiny (např. Brown 2004). Pro teenagery může mít členství v takové skupině symbolický význam dosažení autonomie a rovnosti. Teenageři mohou mít pocit př́slušnosti $\mathrm{k}$ určité subkultuře, která je odlišná od kultury dospělých (Convertino 2002). V různém věku pak mohou být pro uživatele významné rozdílné aspekty a možnosti komunitních serverů. Lidé v období vynořující se dospělosti mohou vyhledávat online komunity proto, aby si v diskuzi s ostatními ujasnili vlastní názory, pro mladší adolescenty může být oproti tomu přitažlivé navazování nových kontaktů. Obecně pak internet, resp. virtuální komunity, mohou mladým lidem nabízet způsob, jak zvládat některé vývojové úkoly, a to především utváření identity či navazování blízkých vztahů (Hall, Parsons 2001). Online komunity nabízejí relativně bezpečné prostředí k experimentům, kde př́ípadná negativní zpětná vazba není tolik ohrožující.

Uvedené výsledky je zároveň třeba vidět v kontextu skutečnosti, že mladí lidí spíše přijali internet jako běžnou součást svého života, orientují se v něm a aktivně se účastní vytváření jeho současné podoby. Vzhledem $\mathrm{k}$ tomu, že prostředí internetu je velmi dynamické, je čím dál složitější vybraný server zařadit do nějaké kategorie (např́klad www.libimseti.cz vznikl jako seznamovací server, ale dnes je spíše klasickým komunitním portálem). Přestává být podstatné, jaký konkrétní server uživatel navštěvuje, významnější se zdá být sledování

13 Většina služeb umožňuje zařadit určitého uživatele do tzv. ,ignore listu“, což znamená, že tento nás pak nevidí online, př́ípadně že se nám nezobrazují jeho př́íspěvky. 
konkrétních motivů uživatelů a jejich online chování - jaké aplikace v rámci serveru používají, s jakými lidmi se stýkají apod.

Významný podíl žáků a studentů mezi účastníky komunit odpovídá skutečnosti, že studující mají více volného času. Internet je v současnosti také samožrejmým a nutným studijním nástrojem (Nalwa, Anand 2003), studenti online tráví velké množství času, přičemž část z něj věnují účasti v online skupinách. $Z$ hlediska sociálního statusu je určující proměnnou především věk uživatele, který ovšem s jeho sociálním statusem úzce souvisí.

Zajímavé jsou výsledky ukazující, že online komunit se častěji účastní dospívající, kteří mají partnera. V úvahu přichází varianta, že prostřednictvím komunitních portálů komunikují tito lidé právě se svými partnery, se kterými aktuálně nemohou být. Současně se online komunit patrně častěji účastní sociálně aktivnější adolescenti, což jsme ostatně ukázali v porovnání průměrných počtů přátel; téma diskutujeme také v následujícím odstavci. Nabízí se tak hypotéza, že sociálně aktivnější adolescenti mají díky větší sociální síti častěji partnery.

Jednou z charakteristik uživatelů, kteří tráví čas v některé z virtuálních komunit, je podle výsledků „Světového projektu o internetu: Česká republika“ vyšší počet přátel oproti ostatním uživatelům internetu. Ke stejnému závěru dospěli např́íklad Hlebec a kol. (2006). Tito autoři ale zároveň upozorňují, že jejich zjištění nevypovídá nic o směru př́padné kauzality. Je otázkou, zda je šiře a intenzita sociálních kontaktů větši díky členství ve skupině, nebo zda jsou společenštější lidé spíše nakloněni se do takové skupiny zapojit, př́padně zde komunikovat právě se svými přáteli z offline světa. Hlebec (2006) dále připomíná, že důležitá je struktura a kvalita sociální sítě, nikoliv jen počet přátel. Také v předkládaném výzkumu se ukázalo, že i přesto, že členové online skupin vykazují ve srovnání s ostatními uživateli internetu vyšší počty přátel, poměr blízkých přátel je u obou skupin stejný. Užitečné zde mohou být úvahy Boyd a Ellison (2007), podle kterých se označení „přítel“ nemusí v kontextu virtuálních komunit vždy vztahovat ke vzájemnému blízkému osobnímu vztahu. Vysledovat, jak účastníci komunit definují online prátele $\mathrm{v}$ porovnání $\mathrm{s}$ tím, jak definují reálné přátele, by umožnilo další analýzu jejich vztahu.

V našem výzkumu jsme sledovali především to, jak účast ve virtuální komunitě ovlivňuje kontakt se členy domácnosti a s přáteli. Podobně jako ve výzkumech Nie a Erbringa (2002) nebo Štětky a Šmahela (2008), i zde respondenti udávají, že vlivem internetu tráví méně času s rodinou. Zároveň jsou ale účastníci komunit častěji v kontaktu se svými přáteli a tráví s nimi díky internetu i více času než lidé, kteří se do online skupin nezapojují. To podporuje zjištění Krauta a kol. (2002), že internet, potažmo zkušenost s online komunitou, může pomoci k většímu zapojení i do „reálné“ komunity. Možné vysvětlení nabízí také Tyler (2002), když ř́íá, že intenzivnějši kontakt, byt' skrze online komunikaci, zvyšuje pocit blízkosti a takto získaná podpora posiluje pocit uspokojení ze vztahu a podporuje následné další zapojení se do tohoto vztahu.

Navýšení kontaktů s blízkými lidmi díky internetu potvrzují i výsledky „Světového projektu o internetu" z dalších zemí (Galácz, Šmahel 2007). V Singapuru 50 \% uživatelů vypovědělo, že internet rozšriřil jejich kontakty s rodinou a přáteli, v Mad’arsku to bylo $21 \%$. Internet se tedy ukazuje být v tomto smyslu prostředkem $\mathrm{k}$ udržování stávajících vztahů (Wellman 2001). Užitečná by pak mohla být informace o tom, jaký podíl z těchto kontaktů tvoří komu- 
nikace s blízkými, kteř́ jsou aktuálně fyzicky nedostupní, do jaké míry tedy internet zprostř̌edkovává jinak těžko dostupné vztahy.

Výsledky také naznačují, že internet, respektive prostředí online komunity, podporuje ve větší míře kontakt s práteli než komunikaci s rodinou. Zde lze nalézt souvislost $\mathrm{s}$ věkem členů komunit a uživatelů internetu. Online komunity slouží častěji pro komunikaci mezi vrstevníky. Přesto se od roku 2006 významně zvýšil počet uživatelů internetu, u kterých se, dle jejich mínění, díky internetu zvýšil jejich kontakt s rodinou. Otázkou je, zda se jedná např́iklad o kontakt se sourozenci, nebo zda tohoto komunikačního kanálu více využívají i rodiče. Vzhledem $\mathrm{k}$ tomu, že poměr uživatelů internetu se u vyšších věkových kategorií významně nezměnil, napovídalo by to $v$ takovém př́ípadě spiše možnosti, že dosavadní uživatelé internetu této generace se jen učí více využívat možností online komunikace.

Účastníci komunit tráví online $\mathrm{v}$ průměru o 6 hodin týdně více než uživatelé internetu, kteří se do těchto skupin nezapojují. S ohledem na „time-displacement“ hypotézu (Nie, Hillygus 2002b) by bylo zajímavé zjistit na úkor jakých činností. Je otázkou, zda je to nutně na konto společenských aktivit, nebo zda jde o čas, který by respondenti i jinak trávili samostatně. Ve srovnání uživatelů internetu a respondentů internet nepoužívajících se sice ukázal signifikantní rozdíl v množství času stráveného u televize, mezi členy a nečleny komunit přitom v tomto směru rozdíl není, stejně jako není u těchto dvou skupin rozdíl v množství času stráveného s rodinou.

Ve vnímání online přátelství není ve většině sledovaných otázek významný rozdíl mezi účastníky komunit a ostatními uživateli internetu. Přesto může skutečnost, že členové komunit jsou více ochotni se svěřovat online se svými intimními problémy, souviset s tím, že v jejich skupině existuje určitá důvěra, jsou zde vybudovány bližší vztahy. Vysvětlení tohoto jevu pouze pomocí konceptu sebe-odhalení usnadněného anonymitou či neviditelností na internetu není postačující. $\mathrm{V}$ takovém př́ípadě by se rozdíl mezi členy komunit a ostatními uživateli nemusel projevit. Přesto přichází v úvahu možnost, že u členů komunit hraje roli spíše než blízké vztahy v komunitě skutečnost, že se na internetu častěji potkávají s lidmi a jsou více zvyklí na online komunikaci.

Členství v komunitě zřejmě není podstatnou podmínkou pro vznik online prátelství, které lze označit za blízké. Respektive komunita nemusí nutně znamenat blízké vztahy, záleží na jejím typu (Boyd, Ellison 2007; Nip 2004). Pro vyvozování dalších závěrů by také byly rozhodující informace o tom, jak dlouho uživatel skupinu navštěvuje, jak je ve skupině angažovaný či za jakým účelem skupinu navštěvuje. Zajímavá je otázka, s jakými lidmi se ve virtuálním světě stýkají uživatelé, kteří se neúčastní dění online komunit, jací jsou jejich online prátelé, odkud se rekrutují. Stejně jako je třeba zvažovat možnost, že online přátelé členů komunit nemusejí nutně pocházet právě z této komunity - v dnešní době Facebooku je velký podíl „online přátel“ tvořen především přáteli z běžného života (Subrahmanyam, Reich, Waechter, Espinoza 2008).

\section{Závěr}

Vzhledem k širokému záběru výzkumu nebyla data věnující se samotným komunitám dostatečně specifická a vzorek účastníků komunit byl relativně malý. Ukazuje se, že virtuální 
komunity mohou zahrnovat velmi rozdílné modely chování, které široký reprezentativní vzorek neodhalí. Deskriptivní data ze „Světového projektu o internetu“ tak spíše otevřela možné směry zkoumání virtuální komunitní scény u nás. Možnost srovnávání výsledků „World Internet Project“ z různých let nabízí zajímavý potenciál pro sledování vývoje této problematiky.

Podrobnější analýza vztahů mezi online a offline komunitami je jednou ze zajímavých možností dalších výzkumů. Můžeme se např́íklad ptát, zda a jak se jednotlivé komunity prolínají, jak k př́padnému prolnutí komunit došlo, jak se mohou navzájem ovlivňovat. Do českých výsledků z roku 2007 také dosud nezasáhl fenomén sociálních sítí, jako je Facebook. Existence těchto globálních komunitních sítí vzbuzuje otázku, zda je př́stup českých uživatelů $\mathrm{k}$ nim něčím odlišný, do jaké míry se do nich Češi zapojují ve srovnání se světem a podobně.

\section{Literatura}

BARGH, John A. ; McKENNA, Katelyn Y. A. Plan $9>$ From Cyberspace: The Implications of the Internet for Personality and Social Psychology. Personality and Social Psychology Review, 2000, roč. 4, č. 1 , s. 57 - 75. ISSN 1088-8683.

BARGH, John A. ; McKENNA, Katelyn Y. A. The Internet and Social Life. Annual Review of Psychology, 2004, č. 55, s. $573-590$. ISSN 0066-4308.

BLINKA, Lukás. The relationship of players to their avatars in MMORPGs: differences between adolescents, emerging adults and adults. Journal of Psychosocial Research on Cyberspace, 2008, č. 1. [cit. 25. 9. 2008]. Dostupné na www: $<$ http://www.cyberpsychology.eu/view.php?cisloclanku=20 08060901>.

BOYD, Danah M. ; ELLISON, Nicole B. Social Network Sites: Definition, History, and Scholarship. Journal of Computer-Mediated Communication. 2007, roč. 13, č. 1. [cit. 19. 7. 2008]. Dostupné na www: $<$ http://jcmc.indiana.edu/vol13/issue1/boyd.ellison.html $>$.

BROWN, Bradford. Adolescents' relationships with Peers. In LERNER, R.M., STEINBERG, L. (eds). Handbook of Adolescent psychology. 2. vyd. New Persey : John Wiley \& Sons, Inc., Hoboken, 2004, s. 363 - 394. ISBN 978-0-47120-948-5.

COGET, Jean F. ; YAMAUCHI, Yutaka ; SUMAN, Michael. The Internet, Social Networks and Loneliness. IT \& Society, 2002, roč. 1, č. 1, s. 180 - 201. [cit. 7.9. 2008]. Dostupné na www: <http://www. stanford.edu/group/siqss/itandsociety/v01i01/>.

CONVERTINO, Gregorio. Teenagers: the internet use and groups on-line and off-line. 2002. [cit. 3. 9. 2008]. Dostupné na www: <http://br.endernet.org/ akrowne/courses/2002/fall/dc/all_papers/gregorio_convertino/project.pdf $>$.

FRANZEN, Axel. Does the internet make us lonely? European Sociological Review, 2000, roč. 16, č. 4, s. 427 - 438. ISSN 0266-7215.

GALÁCZ, Anna ; ŠMAHEL, David. Information Society from a Comparative Perspective: Digital Divide and Social Effects of the Internet. Journal of Psychosocial Research on Cyberspace. 2007, č. 1. [cit. 25. 9. 2008]. Dostupné na www: <http://www.cyberpsychology.eu/view.php?cisloclank $\mathrm{u}=2007072401>$.

GOTVED, Stine. Spatial Dimension in Online Communities. Space and Culture, 2002, roč. 5, č. 4, s. 405 - 414. ISSN 1206-3312. 
HALL, Alex S. ; PARSONS, Jeffrey. Internet Addiction: College student case study using best practises in cognitive behavior therapy. Journal of Mental Health Counseling, 2001, roč. 23, č. 4, ISSN 0193-1830.

HLEBEC, Valentina ; MANFREDA, Katja Lozar ; VEHOVAR, Vasja. The social support networks of internet users. New media \& society, 2006, roč. 8, č. 1, s. 9 - 32. ISSN 1461-7315.

HORRIGAN, John B. ; RAINIE, Lee. Emails That Matter: Changing Patterns of Internet Use Over a year's Time. IT \& Society, 2002, roč. 1, č. 1, s. $135-150$.

HOWARD, Philip E. N. ; RAINIE, Lee ; JONES, Steve. Days and Nights on the Internet The Impact of a Diffusing Technology. 2001. [cit. 7. 9. 2008]. Dostupné na www: <http://faculty.washington. edu/pnhoward/publishing/articles/daysandnights.pdf $>$.

KOLLOCK, Peter ; SMITH, Marc A. Communities in Cyberspace. 1999. [cit. 28. 7. 2008]. Dostupné na www: $<$ http://www.sscnet.ucla.edu/soc/faculty/kollock/papers/communities_01.htm>.

KRAUT, Robert ; PATTERSON, Michael ; LUNDMARK, Vicki ; KIESLER, Sara ; MUKOPADHYAY, Tridas ; SCHERLIS, William. Internet Paradox. A Social Technology That Reduces Social Involvement and Psychological Well-Being? American Psychologist, 1998, roč. 53, č. 9, s. 1017 - 1031. [cit. 15. 5. 2008]. Dostupné na www: <http://www.cs.cmu.edu/ kiesler/publications/PDFs/kraut98InternetParadox.pdf $>$.

KRAUT, Robert ; KIESLER, Sara ; BONEVA, Bonka ; CUMMINGS, Jonathon ; HELGESON, Vicki ; CRAWFORD, Anne. Internet Paradox Revisited. Journal of Social Issues, 2002, roč. 58, č. 1, s. 49 - 73. ISSN 0022-4537.

McKENNA, Katelyn Y. A. ; GREEN, Amie S. ; GLEASON, Marci E. J. Relationship formation on the Internet: What's the big attraction? Journal of Social Issues, 2002, roč. 58, č. 1, s. 9 - 31. ISSN 0022-4537.

MEMMI, Daniel. The nature of virtual communities. AI \& Society, 2006, roč. 20, č. 3, s. 288 - 300. ISSN 0951-5666.

NALWA, Kanwal ; ANAND, Archana Preet. Internet Addiction in Students: A Cause of Concern. CyberPsychology \& Behavior, 2003. roč. 6, č. 6, s. 653 - 656. ISSN 1094-9313.

NIE, Norman. Sociability, Interpersonal Relations, and the Internet: Reconciling Conflicting Findings. American Behavioral Scientist, 2001, roč. 45, č. 3, s. 420 - 435. ISSN 1552-3381.

NIE, Norman ; ERBRING, Lutz. Internet and Society: A Preliminary Report. IT \& Society, 2002, roč. 1, č. 1, s. 275 - 283. [cit. 7. 9. 2008]. Dostupné na www: <http://www.stanford.edu/group/siqss/itandsociety/v01i01/>.

NIE, Norman ; HILLYGUS, Sunshine D. The impact of Internet Use on Sociability: Time-Diary Findings. IT \& Society, 2002a, roč. 1, č. 1, s. 1 - 20. [cit. 7. 9. 2008]. Dostupné na www: <http://www.stanford.edu/group/siqss/itandsociety/v01i01/>.

NIE, Norman ; HILLYGUS, Sunshine D. Where Does the Internet Time Come From?: A Reconnaissance. IT \& Society, 2002b, roč. 1, č. 2, s. 1 - 20. [cit. 7. 9. 2008]. Dostupné na www: <http://www. stanford.edu/group/siqss/itandsociety/v01i02/>.

NIP, Joyce Y. M. The relationship between online and offline communities: the case of the Queer Sisters. Media, Culture \& Society, 2004, roč. 26, No. 3, s. 409 - 428. ISSN 1460-3675.

RHEINGOLD, Howard. A Slice of Life in My Virtual Community. 1992. [cit. 3. 9. 2008]. Dostupné na www: $<$ http://www.cs.indiana.edu/docproject/bdgtti/bdgtti_18.html $>$.

RHEINGOLD, Howard. The Virtual Communities. Homesteading on the Electronic Frontier. 1993. [cit. 3. 9. 2008]. Dostupné z www: <http://www.rheingold.com/vc/book/>.

SUBRAHMANYAM, Kaveri ; REICH, Stephanie M.; WAECHTER, Natalia ; ESPINOZA, Guadalupe. Online and offline social networks: use of social networking sites by emerging adults. Journal of Applied Developmental Psychology, 2008, roč. 29, č. 6, s. 420 - 433. ISSN 0193-3973. 
ŠMAHEL, David. Attending Online Communities: Culture of Youth? In: SUDWEEKS, F., HRACHOVEC, H. \& ESS, Ch. (eds.). Cultural attitudes towards technology and communication. Australia : School of Information Technology, Murdoch University, 2008, s. 446 - 451. [cit. 25. 9. 2008]. Dostupné na www: <http://www.terapie.cz/materials/catac2008-smahel.pdf>.

ŠTĚTKA, Václav; ŠMAHEL, David. Attributes of Participation in Online Communities among Czech Internet Users. Observatorio, 2008, roč. 2, č. 3, s. 39 - 52. ISSN 1646-5954.

TYLER, Tom, R. Is The Internet Changing Social Life? It Seems the More Things Change, the More They Stay the Same. Journal of Social Issues, 2002, roč. 58, č. 1, s. 195 - 205. ISSN 0022-4537.

VACULÍK, Martin; HUDEČEK, Tomáš. Vývoj partnerských vztahů vzniknuvších v prostředí internetu. Československá psychologie, 2005, roč. 59, č. 2, s. 159 - 176. ISSN 0009-062X.

WELLMAN, Barry ; SALAFF, Janet ; DIMITROVA, Dimitrina ; GARTON, Laura ; GULIA, Milena ; HAYTHORNTHWAITE, Caroline. Computer network as social networks: Virtual Community, Computer Supported Cooperative Work and Telework. Annual Review of Sociology, 1996, roč. 22, s. 213 - 38. ISSN 0360-0572. [cit. 25. 7. 2008]. Dostupné na www: <http://www.chass.utoronto. $\mathrm{ca} / \sim$ wellman/publications/>.

WELlMAN, Barry ; GULIA, Milena. Net Surfers Don't Ride Alone: Virtual Communities as Communities. 1997. [cit. 25. 8. 2008]. Dostupné z www: <http://www.chass.utoronto.ca/ wellman/publications/netsurfers/netsurfers.pdf $>$.

WELLMAN, Barry ; HAASE, Anabel Q. ; WITTE, James ; HAMPTON, Keith. Does the Internet Increase, Decrease, or Supplement Social Capital?: Social Networks, Participation, and community commitment. American Behavioral Scientist, 2001, roč. 45, č. 3, s. 436 - 455. ISSN 1552-3381.

WELLMAN, Barry. Psychical Place and Cyberplace: The Rise of personalized Networking. International Journal of Urban and Regional Research, 2001, roč. 25, č. 2. ISSN 0309-1317. [cit. 25. 9. 2008]. Dostupné z www: <http://www.chass.utoronto.ca/ wellman/publications/individualism/ ijurr3a1.htm>.

\section{Autorka a autor}

Martina Veselá je doktorandkou na Fakultě sociálních studií Masarykovy univerzity v Brně. Věnuje se psychologii internetu, především problematice komunitních portálů a sociálních sítí a dále fenoménu pro-ana hnutí na internetu. Mimo svět internetu se zajímá o ericksonovskou a narativní terapii.

Kontakt: martuli@mail.muni.cz

David Šmahel pracuje v Institutu výzkumu dětí, mládeže a rodiny na Fakultě sociálních studií Masarykovy univerzity. David Šmahel se zabývá výzkumem chování dětí a adolescentů v prostředí internetu, zajímá ho konstruování online identit, utváření a vývoj virtuálních vztahů a oblast závislostního chování na internetu. Je také editorem časopisu „Cyberpsychology: Journal of Psychosocial Research on Cyberspace“"

Kontakt: smahel@fss.muni.cz 